\title{
Migration, Refugees, and Racism in South Africa
}

\author{
Jeff $\mathrm{H}$ andmaker and Jennifer Parsl ey
}

\section{Abstract}

The paper looks at South Africa's complex history and policies of racism, social separation and control and the impact that this has had on the nature of migration and refugee policy. The paper argues that this legacy has resulted in policy and implementation that is highly racialized, coupled with a society expressing growing levels of xenophobia.

Some causes and manifestations of xenophobia in South Africa are explored. It further examines how actions of police and civil servants can mirror the sentiments of the general public, further disadvantaging refugees and migrants.

The outcomes of the WCAR are discussed with acknowledgment of the positive gains made for refugees and asylum seekers. The implications for implementation are debated in light of the attacks on the USA.

In conclusion, a number of recommendations are made including the need for ongoing public awareness strategies, the value of the WCAR Declarations as lobbying tools, a pragmatic and democratic policy process and the need to highlight development concerns in approaches to address these issues.

\section{Résumé}

Cet article examine l'histoire complexe de l'A frique du Sud et ses politiques racistes et ségrégationnistes et l'impacte que cela a eu sur la politique sur l'immigration et les réfugiés. L'article soutient que ce lourd patrimoine a donné naissance à une politique et une pratique fortement imprégnées par des considérations de race ainsi qu'une société qui fait montre de niveaux croissants de xénophobie.

Sont ensuite explorées certaines causes et certaines manifestations de la xénophobie en Afrique du Sud. Puis, l'article se penche sur la manière dont les actes des forces policières et des fonctionnaires de l'état peut refléter les sentiments du grand public, préjudiciant ainsi davantage les réfugiés et les immigrants.

Les résultats de la CM CR ( «Conférence mondiale contre le racisme, la discrimination raciale, la xénophobie et l'intolérance qui y est associée ») sont examinés et les gains obtenus en faveur des réfugiés et des demandeurs d'asile sont salués. Les implications pour l'exécution (du programme d'actions) sont discutées à la lumière des attaques contre les États $U$ nis.

Pour conclure, l'article propose un certain nombre de recommandations, dont la nécessité de mettre en place des stratégies pour garder l'opinion publique bien informée, la valeur des Déclarations de la CM CR en tant qu'outils pour le lobbying, un processus démocratique et pragmatique pour développer des lignes directrices politiques et la nécessité de mettre en valeur les enjeux touchant le développement à l'intérieur des solutions proposées pour résoudre ces problèmes.

\section{Introduction}

The images we have seen are abominable, horrible. It's an assault against human rights. ${ }^{1}$

$\mathrm{T}$ his was the reaction by the $M$ ozambique M inister of Labour to a police training video that reached national and international television, showing M ozambican migrants being attacked by police officers and dogs in a "training exercise." The incident deeply shocked the conscience of even the most cynical of ob- 
servers, not only in the sheer level of the violenceportrayed, but also in the way it rekindled memories of the apartheid-style police brutality.

W hile media coverage and public debates on violence and racism in South Africa are nothing new, debates on migration, refugees, and xenophobia have only relatively recently hit the public spotlight, and links between racism and xenophobia are rarely made. As this article will seek to amplify, the nature of migration and refugee policy and the manner in which it is implemented in South Africa is highly racialized, stemming from the country's complex history and policies of social separation and control. Equally, the growing xenophobia in the country is profoundly characterized by racism and a high degree of violence.

\section{Nature of Migration to South Africa ${ }^{2}$}

Since 1994, the context of migration to South Africa has dramatically altered. The democratic government has rapidly embraced entry into the global arena, pursuing neo-liberal economic policies aimed at encouraging the free movement of international trade and capital. An area of contradiction, however, is related to the free movement of people, particularly African unskilled economic migrants (often in the form of informal sector traders) and refugees.

Contemporary migration to South Africa is characterized by a number of factors, ranging from individuals taking up contract labour to work in the country's huge mining and agricultural industries to persons seeking protection from persecution, human rights violations, and war.

$M$ any migrants come from neighbouring $M$ ozambique. In the past these included refugees fleeing the war in M ozambique, ${ }^{3}$ braving a collection of horrors, including dangerous wild animals in Kruger National Park (which borders both countries) and a fence generating a lethal electric voltage, in their desperation to avoid border control officials in order to reach relative safety in neighbouring South Africa.

N owadays, the reasons for migrating from M ozambiqueare related largely to economic factors rather than persecution or war, al though sincethemaintaining of the RomePeaceAccord between Renamo and Frelimo in 1992, M ozambique has been beset with a crippling economy and environmental disasters generating a "new generation" of forced migrants, not least the devastating floods that displaced hundreds of thousands in 2000.

M igration to South Africa from other countries is believed by many to have increased. Media reports on migration abound with headlines such as, "An Invasion to be H alted," "6 Million Headed Our Way," and "Africa Floods into Cape Town." 4 H owever, the actual numbers of migrants entering South Africa in recent years continue to be heavily contested, ranging from conservative estimates of several hundred thou- sand, to heavily exaggerated figures ranging into the "millions," supported by "pseudo-scientific" data. ${ }^{5}$ W hatever the numbers, it is clear that the nature of most regional migration is "circular," with migrants expressing little wish to remain permanently. ${ }^{6}$ Furthermore, whileemployer demand playsa significant rolein stimulating irregular/undocumented cross-border migration, "enforcement targets employees, not employers." "

\section{Racialized Nature of Migration Policy in South Africa}

Prior to 1994, South Africa was infamous throughout the world for its racialized policies and seemingly limitless measures of social control. Migration control in South Africa was in line with apartheid-era policy and has always been restrictiveand security orientated, with similar origins as the notorious pass laws, as a cornerstone of the previous government's policy of influx control, which were enforced against black people in South Africa as a means of controlling domestic migrant labour. The pass laws wereparticularly harsh, as is reflected in police arrest statistics; prior to the abolition of influx control, pass law offences featured disproportionately high. ${ }^{8}$

In a sense, influx control was effectively "transferred" to the borders in the form of the Aliens Control Act, a compilation of various pieces of immigration legislation, the latest version coming into force in 1991. South Africa's policy on entry and residence, including temporary migration, immigration (permanent residence) and, until recently, refugee status determination, had fallen under the Aliens Control Act. The Act wasconceptualized to primarily exclude the entry of Indians (during the early part of the twentieth century), Jews (during the Second World War) and communists (especially during the Cold War).

The broad discretion accorded by the Act facilitated generous entry to anti-communists from Eastern Europe and immigrants from W estern Europe, many of whom were sympathetic to the nationalist cause. W hile this discretion also prevented entry to foreign activists and journalists, it primarily operated to exclude black migrants, whose entry was strictly limited to bilateral, contract-labour treaties between South Africa and neighbouring states to provide cheap labour, mainly for the mining and agricultural industries. Once in South Africa, officially or not, black migrants (predominantly from M ozambique) fell under the influx control legislation.

The Act (even in its latest versions) was rooted in the previous government's overarching policy of apartheid, and was thus a policy "rooted in racism" as Peberdy and 
Crush have observed. ${ }^{9}$ Even Billy M asethla, the Director General for the Department of Home Affairs, concurs and has described the Aliens Control Act as "draconian" and an "apartheid dinosaur." 10

Despite tremendous pressure from the international community, the previous government showed itself to be stubbornly resistant to change, reinforcing its control through a civil service and police force that were:

... alwaysin thefront linein theenforcement of apartheid ... (and) ensured that black South Africans were kept in their places in segregated and inferior institutions. ${ }^{11}$

The department designated to enforce migration policy today is the very same that, in the past, was responsible for enforcing influx control. The "sunset clause," which was part of South Africa's negotiated settlement leading to democracy, ensured job security for most in the civil service. This has resulted in a government where those at the top may have changed, but many of the apartheid era officials (and their unforgiving attitudes) are still there.

The Lindela Deportation Centre provides stark evidence of the continued racialized nature of migration policy and implementation in South Africa. This facility faced considerable scrutiny by the South Africa Human Rights Commission after an enquiry into a range of human rights abuses; ${ }^{12}$ one will not find in it any of the thousands of European tourists who have overstayed their visas. The facility can hold up to 1,500 detainees, and it has been shown that those being held as suspected undocumented migrants are people whose skins are darker, clothes morecolourful, vaccination marks in different places; Africans who are unable to speak a local African language; and peoplewho have a host of other physical attributes not deemed "South African" and therefore "illegal."

There is also current discussion on proposed reception/detention centres for asylum seekers to belocated far from urban centres. Whether these centres would accommodate, for example, possible whiteasylum seekers from Zimbabwe without condemnation is doubtful.

Policy is therefore not in line with contemporary realities of modern migration. One reality is that skills are leaving the country (in the form of mostly white emigrants), while skilled immigrants often face impossible hurdles. Another reality (mentioned earlier) is that the majority of migrants enter South Africa mainly for the purposes of short-term trading or employment, but with no intention to remain. A further reality is that a far smaller group of migrants (refugees) are entering the country seeking protection from political persecution or war and other disasters. M ost forms of these activities are aimed at survival and, contrary to the aspirations of the Act, uncontrollable. However, they might be managed in a more appropriate and pragmatic manner, not least through an analysis of South Africa's objective labour needs and an acknowledgement of the positive contributionsinformal sector trade can and does make to South Africa and Southern African economies.

\section{Efforts to Reform ${ }^{13}$}

The first migration policy reform came in 1995, with a statutory amendment ${ }^{14}$ to the Aliens Control Act No. 96 of 1991. It was Parliament's intention to bring the Act more in line with the country's new constitution. Before being amended in 1995, s. 55 of the Act even provided that no decision of the Department was reviewable by a court or tribunal, and persons could beheld in detention indefinitely, without judicial review. ${ }^{15}$ The 1995 Amendment removed this provision and provided that detention for periods beyond thirty days ought to be subject to review, although in practice it appeared that this was being inconsistently applied. ${ }^{16}$ In short, despite the reforms, there were still concerns that the Aliens Control Act fell far short of constitutional expectations. ${ }^{17}$ Clearly, more comprehensive reforms were necessary.

Attempts to overhaul the country'smigration policies were at one stage pragmatic in their approach and characterized by active civil society involvement, as demonstrated by the draft Green Paper on International $M$ igration and Refugees Act. Both documents, appearing in 1997 and end of 1998 respectively, proposed practical measures to address the country's objective labour requirements, and incorporated a principled commitment to human rights. However, this approach was short-lived, as it become increasingly evident that the government was to sacrifice this approach in favour of a more security and control oriented approach.

The W hite Paper on International M igration, the Immigration Bill, and the Regulations to the Refugees Act, presented in M ay 1999, February and April 2000 respectively, explicitly condemned racism and xenophobia, yet they also made it clear where the government ultimately stood in dealing with migration - a position not dramatically different from the past. The security and control oriented approach was evident in the focus on deterring undocumented migrants and "bogus" asylum seekers. ${ }^{18}$ The policy proposals pursue a strategy overwhelmingly aimed at punishing ${ }^{19}$ those responsible for trafficking and employing foreigners on a permit basis. Further, it is the drafters' intention that the enforcement of border controls rely on the community. In its earlier drafts, it was proposed that a professional security service be established in order to identify and apprehend unwanted foreigners, although we now understand that this idea 
was resisted by other government agencies. W ith al ready high levels of xenophobia, human rights organizations have raised concern over the implications of encouraging the community to act as "whistle-blowers" against suspected undocumented migrants.

The Aliens Control Act is likely to berepealed this year, and it is hoped that the last vestiges of the apartheid dinosaur will finally be buried; however, there is considerable concern whether the legislation that replaces it will appropriately address the country's migration challenges and increasing levels of xenophobia. ${ }^{20}$

\section{Asylum Determination Regime: Policy and Capacity Challenges}

Reforming refugee policy has received comparatively more attention. The RefugeeAct was passed in 1998 and entered into force in April 2000. The development of a workable structure, however, for administering the country's asylum determination regime has been complicated by a number of factors, both policy and capacity related.

South Africa's Refugee Act 1998 has its origins in the country's Aliens Control Act and, although representing a significant departure from the ACA, has in numerous respects failed to provide adequate due process guarantees to applicants, and is implemented in an ad hoc manner. ${ }^{21}$ Capacity-related problems are largely a consequence of the fact that the issue is still quite new in South Africa, and that the asylum system has fit uncomfortably within the country's immigration system. ${ }^{22}$
There are not enough resources (especially staff, the majority of whom urgently need training) on hand to process the steadily increasing numbers of asylum applications. ${ }^{23}$

The South African Human Rights Commission and migration experts, amongst others, have raised serious concerns about the consistent failure to achi eve satisfactory standards of administrative justice. ${ }^{24}$ This is evident through unfair delays of applications, racist and discriminatory practices, and inconsistent application of the law.

While the number of applications received appears to have stabilized in recent years (Figure 1; note that these are cumulative statistics) and cannot be regarded as presenting a situation of "mass influx," as compared with other countries on the continent, the cumbersome system places a heavy burden on those struggling to re-establish their lives as refugees in South Africa. ${ }^{25}$

Of particular concern to human rights activists arethe implications of the section 22 Asylum Seeker permit, issued in terms of the 1998 Refugees Act. Designed to deter "bogus" asylum claims, the permit removes the right to work and study for asylum seekers for the 180 days while the claim is being processed. ${ }^{26}$ In this interim period, no social assistance is made available and the common refrain from asylum seekers is, "W e are given a piece of paper from the Department of Home Affairs. Can we eat this piece of paper?" 27

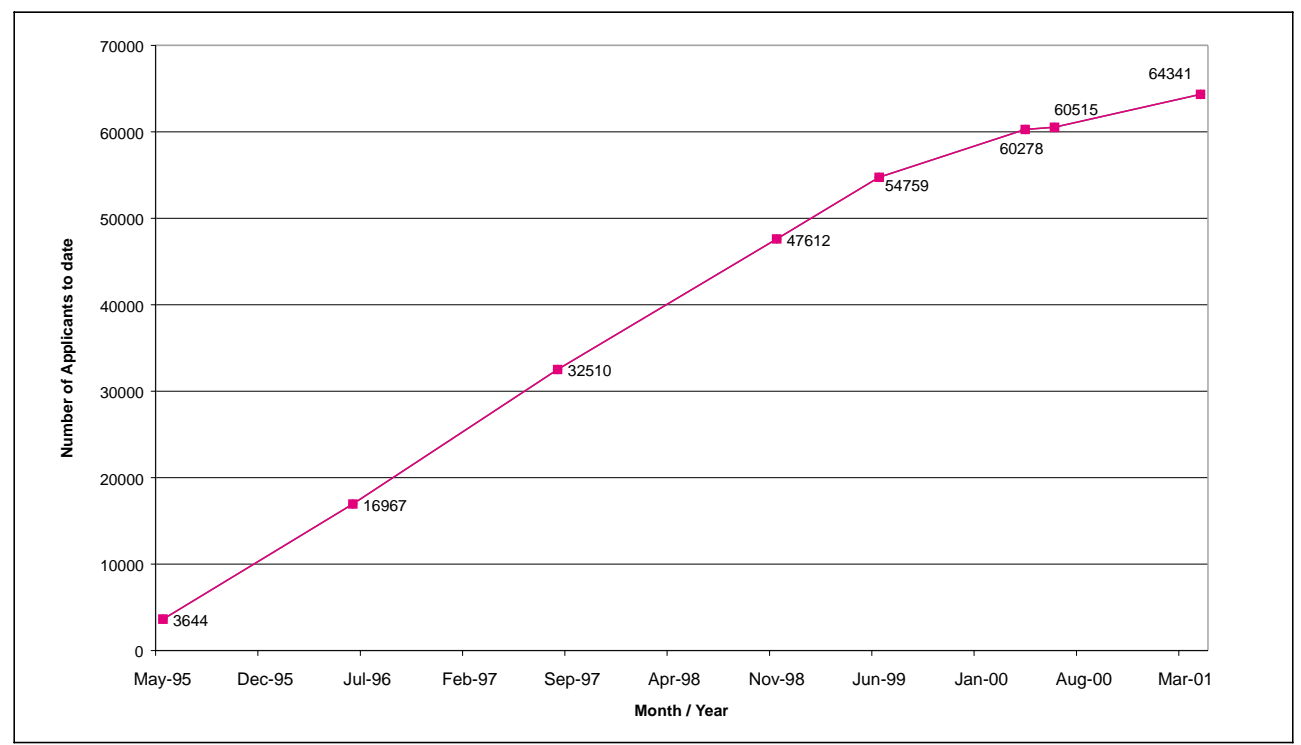

Figure 1: Applications Received to Date (1995-2001, cumulative) 
Table 1

Refugee Applications in South Africa: 1995- 2001 (C umulative Statistics)

\begin{tabular}{llrrrr} 
Source & Dated & Received & Approved & “Refused"* & Outstanding \\
\hline UNH CR (State of the W orld's Refugees) & M ay 1995 & 3.644 & 383 & 517 & 2.744 \\
DHA / U NHCR (recorded figures) & June 1996 & 16.967 & 1.915 & 5.649 & 9.403 \\
DHA / U NHCR (recorded figures) & Aug. 1997 & 32.510 & 4.002 & 6.118 & 22.390 \\
DHA ** & N ov. 1998 & 47.612 & 7.927 & 19.031 & 20.654 \\
DHA / U NHCR (recorded figures) & June 1999 & 54.759 & 8.504 & 25.020 & 21.235 \\
DHA / U NHCR (recorded figures) & Apr. 2000 & 60.278 & 15.006 & 29.219 & 16.053 \\
DHA / U NHCR (recorded figures) & June 2000 & 60.515 & 15.116 & 29.899 & 15.500 \\
DHA / U NHCR (recorded figures) & Apr. 2001 & 64.341 & 17.198 & 34.184 & 12.959 \\
* “R efused" includes: Rejected, cancelled, expired, withdrawn and manifestly unfounded applications \\
** Speech by Deputy M inister of H ome Affairs to Parliament, N ovember 5, 1998
\end{tabular}

W ith no access to social assistance and removal of the right to economic participation, asylum seekers find themselves in an alarming situation of "enforced destitution," denying them the ability to survive legally. ${ }^{28}$ Once refugee status has been obtained, a number of barriers continue to impede the ability of refugees to integrate and meaningfully participate in society. There is a need for government to reconsider the inhumane restrictions that the section 22 permit imposes on asylum seekers and to address the issue of refugees and asylum seekers holistically. This requires commitment, through policy and information, to provide material assistance and support for asylum seekers and refugees that extends beyond the provision of legal protection. ${ }^{29}$

\section{Racism and Xenophobia}

On a spring day in September 1998, a horrifying incident took place on a train between Johannesburg and Pretoria. A mob of unemployed South Africans demonstrating against the presence of foreigners in South Africa murdered one M ozambican and two Senegalese asylum seekers, who were scraping a living selling sweets to passengers. ${ }^{30}$ The public's response, however, was muted. The victims were black foreigners.

According to $\mathrm{O}$ kkoth-O bbo this is an alarming trend visible in many other African countries:

Xenophobia, hatred and intolerance against foreigners has mushroomed in Africa. Oncerenowned for thegenerous and hospitable manner in which it received refugees and foreigners, refugees and foreigners now often find that they have more to fear from the ordinary citizens than from agents of the state. ${ }^{31}$
Xenophobia, although a contested term, is widely defined as the irrational fear of the unknown, the fear or hatred of foreigners by nationals against non-nationals. Xenophobia is largely based on unfounded myths and stereotypes with foreigners scapegoated for domestic social and economic problems. In South Africa foreigners are blamed for the high crime rate, the HIV/AIDS pandemic, the high levels of unemployment, and the lack of social services. It would appear that in South Africa, foreigners and refugees fear both the ordinary citizens and agents of the state.

Xenophobia is manifested in a number of ways ranging from derogatory terms to unacceptable levels of violenceagainst foreigners. Asylum seekers and refugees are in many ways particularly vulnerable since they are more obviously "distinguishable" from South Africans and furthermorearemore "visible" because of their legal status.

There are a number of arguments/hypotheses as to why xenophobia is manifesting and growing in South Africa. Some will be mentioned here, bearing in mind that morecomprehensive research is needed in thisfield.

South Africa's isolation

The xenophobic violence that South Africa is experiencingisin many ways a legacy of thecountry's racist history. It is also the product of a futile, isolationist policy designed to intimidate and control foreigners. South Africa's past exclusion from the international community has resulted in theinability to tolerate and accommodate difference. Hobsbawm describes xenophobia "as the 
product of social transition, as a defence against the anxiety induced by 'the unknown'." 32

\section{Economic deprivation and scapegoating}

Exploitativeeconomic policies and continued wars and conflict have had a negative effect on the social and economic development of Africa with major implications for migration. Central to xenophobic tensions is the competition for scarce resources and the perception that non-nationals pose a significant threat in terms of limited opportunities and resources.$^{33} \mathrm{Added}$ to this is the seemingly endless duration of conflicts in Africa leading to compassion fatigue and declined empathy in assisting refugees and asylum seekers. Some South Africans view the South African liberation struggle as a real struggle compared with ethnic and religious conflicts elsewhere on the continent.

When confronted with xenophobic violence, many whites do not perceive this issue as affecting their own security directly, and so tend to ignore it. This kind of response is reminiscent of the previous government's declarations describing most of the violencein the country as being "black on black." On the other hand, there are white South Africans claiming, in an odd kind of solidarity, that the government should put South Africans first, blaming foreigners for the country's social and economic ills - an argument that also provides a convenient distraction from discussions on economic redistribution.

\section{Democracy, The Nation and 'Others'}

South Africa, understandably, is in the process of constructing a national identity out of a violent and fractured past, contested between disparatecultures and communities. In this construction, Africa features prominently via the current South African President's African Renaissance ideal. These two processes, nation-building and Africa-building, operate simultaneously; but they are producing tensions and contradictions on the ground. ${ }^{34}$

In this new political landscape, the government is under pressure to deliver to a voting electorate. Voting populations have a growing sense of their rights and entitlements, thus laying claim to thelimited socio-economic resources available. If foreigners are perceived as a threat to the development of the nation, it is easier for government departments, particularly with regard to migration policy, to pander to populist sentiments rather than be unequivocal in their commitment to human rights. Billy M asethla, the Director General of the Department of $\mathrm{H}$ ome Affairs, concedes that the department "finds itself increasingly locked between, on the one hand, human rights considerations on the handling of theseforeigners and, on the other, growing xenophobic attitudes towards them among South Africans." ${ }^{35}$
Xenophobia and Racism

As mentioned previously, South Africa has only recently emerged from a violent, racially divided past. According to O kkoth-Obbo, xenophobia typifies a society in contradiction with itself: "The point is that xenophobes demonstrate resistanceto diversity not only of external origin, but internally as well." ${ }^{36}$

Crucial in constructing a nation is a common destiny. Governments trying to unitean internally fractured racist society may embark on a nation- building project that constructs the "insiders" as the nationals and the "outsiders" as thenon-nationals. Y uval-D avis argues that the common destiny needs to be enhanced through the construction of a "symbolic border guard," the creation of boundaries dividing the world into "us" and "them." ${ }^{37}$ Research in South Africa has shown that xenophobic attitudes are held at all levels of society across race, class, and gender divides. ${ }^{38}$

\section{Lack of Knowledge}

If knowledge is power, it is clear why South Africans and foreigners are disempowered in contemporary South Africa. Basic information-Who is a refugee? Who is a foreigner? Wheredo "they" comefrom? What are "they"' doing here? What are their rights in South Africa? - are not known, not only by the average South African, but also by key civil servants and law enforcement officials.

\section{Institutionalized Racism and Xenophobia}

There is a strong sensitivity in South Africa to claims of being racist; reactions are often hostile and deeply polarized. H owever, the screening of the police training video on national television was so utterly shocking that it did manage to stimulate some debate as to whether the incident smacked of racism, or (gruesome as it was) was just the latest in a series of anti-foreigner attacks.

Joyce Tlou, lawyer and national coordinator of the $N$ ational Consortium on Refugee Affairs (NCRA) in South Africa, was unequivocal in her response: "black people felt very strongly that the issue is not about dogs and brutality but racism and that this is what should be addressed." The South African Human Rights Commission, in a press release on the incident, highlighted the links between racism and xenophobia:

The fact that the victims were black, foreign and may have been here without the proper authorisation obviously contributed to the police thinking that no matter what pain they inflicted, they would not beheld accountable. There is a direct link between the alarming degree of xenophobia and racism prevailing in our society and 
the existence of such beliefs in people who are entrusted with the job of upholding the law. ${ }^{39}$

Like violence in general, police brutality is an enduring problem in South Africa. The incident described at the beginning of this article, disturbing as it was, merely represents the tip of the iceberg, the latest in a flood of allegations that has overwhelmed the capacity of the South African Independent Complaints Directorate (ICD) monitoring theactivities of the police in South Africa. The link between the brutality of the police and racism is also well established, the victims being almost invariably black and often treated in a racist manner, as both Tlou and international observers such as Human Rights W atch ${ }^{40}$ and Amnesty International ${ }^{41}$ have observed. It is therefore no coincidence that the victims of "xenophobic" attacks are, almost invariably, black people from African countries.

In M arch 2000, an exceptionally xenophobic exercise was undertaken by the South Africa Police Service (SAPS). Called Operation Crackdown, it propounded to be an anti-crime blitz with expressed goals to "thoroughly ventilate all criminal elements and illegal immigrants." ${ }^{42}$ Targeting areas with large migrant communities such as $\mathrm{H}$ illbrow, the Operation led to countless al legations of human rights abuses, including genuine refugee papers being destroyed and refugees being herded up and sent to the Lindela Deportation Camp.

Further incidences have sparked outrage within the South African community. On March 12, 2001, Sylvia Manda, a South African teacher in H illbrow, was arrested, assaulted, and detained for several hours on suspicion of being an undocumented immigrant. When the police captain, Bongani Dube, was asked to elaborate on what grounds they suspected her of being an illegal immigrant [sic], Dube replied, "complexion, facial appearance, accent and her style of dressing." 43 The case of Sylvia $M$ anda is not unique, with other darker-skinned South Africans reporting similar incidences. O peration Crackdown and cases such as that of Sylvia Manda have a further implication in reinforcing existing stereotypes of foreigners and criminality.

Another, less publicized, implication is the cost of human rights violations to the South African taxpayer: Sylvia M anda and many of the victims of O peration Crackdown have instituted civil claims against the police running into millions of rands.

Responsibility for attacks and hostility against foreigners does not lie on the doorstep of the police alone, however. Indeed, in democracies the world over, police and civil servants often mirror the sentiments of the general public as a kind of moral justification for their actions, and South Africa is no exception.

Civil servants provide the hands-on delivery, which is essential to implementation of policy. As the gatekeepers of access to legal documentation, safety and security, education, housing, and a host of other social services, civil servants are powerful figures in the lives of asylum seekers and refugees. Presently, the conduct of many government officials depends largely on individual feelings and opinions rather than on professional human rights conduct. ${ }^{44}$

Compounded by thelack of a coherent policy, inadequate information on the social and economic needs of refugee and asylum seekers, lack of knowledge by refugees and asylum seekers on their rights of access and, most especially, the hostility and negative attitudes that refugees and asylum seekers face when attempting to access government services, it is not surprising that an asylum seeker recently protested, "Xenophobia in the civilian population is al most easier to manage... It is the institutionalized xenophobia of government officials that leaves us feeling the most powerless." ${ }^{45}$

World Refugee Day, June 20, 2001, was used as an opportunity to engage government on some of the crucial legal, socio-economic, and safety concerns facing refugees and asylum seekers. A workshop titled "Refugee Life in South Africa: Building Partnerships towards Better Solutions" was planned as a follow-up to the South African National Conference on Racism held in September 2000. Article 30 of the South African Millennium Statement on Racism and Programme of Action states:

Appropriate social assistance for asylum seekers and refugees needs to be considered in close co-operation with NGOs, which would help in their integration into South African society and increase their contribution in skills and expertise towards national development. The Conference calls for the development of closer co-operation between government, the National Consortium on Refugee Affairs and the UNCHR in order to co-ordinate improved services to asylum seekers and refugees.

The workshop brought together key government departments, NGOs, faith-based organizations, theNCRA, the Roll Back Xenophobia Campaign, and the UNHCR to begin deliberations on the policies of asylum and to consolidate processes needed to holistically address the grim realities facing refugees and asylum seekers. The workshop also addressed the barriers that racism and xenophobia pose in the access to quality services and integration into the South African society.

Furthermore the South African Police Service(SAPS) is currently working in partnership with human rights organizations ${ }^{46}$ in a series of pilot workshops aimed at sensitizing the police to the rights of refugees and non- 
nationals and the obligations of SAPS in ensuring their safety and security.

\section{The W orld Conference against Racism in Durban}

The Conference condemns any form of co-operation with South Africa... the international community is exerting all its efforts toward the objective of completely isolating the racist regime of South Africa. ${ }^{47}$

These were the words of the Declaration and Programme of Action adopted at the World Conference to Combat Racism and Racial Discrimination 1983. Indeed almost the entire Declaration of 1983 was focussed on outrage against apartheid. It was therefore not subtle irony, but rather a continuation of the country's globally celebrated democracy, that brought the next W orld Conference to the "rainbow nation" of South Africa.

The W orld Conference Against Racism (WCAR) ${ }^{48}$ accompanied by a parallel NGO Forum, was undoubtedly one of the most significant human rights events to take place at an international level in the last decade. It is perhaps for this reason alone that the number of items on the meeting's agenda proved to be so considerable, if not overwhelming, each item certainly worthy of a separate conference on its own. The significant media attention during the early stages of the conference was a positive illustration of the increased awareness of human rights issues sincethelast meeting, which took place in 1983. On the other hand, the large agenda was also a sad reflection that there continues to be a great deal of human rights abuse taking place around the world as well as a deepening dissatisfaction that past abuses remain unresolved.

It was unfortunate that considerable attention on the part of NGO s and the media focussed overwhelmingly on issues at the N GO Forum dealing with thesituation in Israel / Pal estine. The reactionary response by the United States and Israel of withdrawing their delegations in response to an NGO-produced Draft $D$ eclaration (soon followed by a drastic reduction in the delegations of European countries) was even more disappointing. These events had the impact of drawing attention away from the many other areas being positively addressed at WCAR, not least issues pertaining to the treatment of migrants, migrant workers, and refugees.

$W$ ith regard to refugees and asylum seekers, it is interesting to note that in the 1983 Declaration refugees are largely referred to in the context of the anti-apartheid liberation struggleand those fleeing theracist South A frican regime of the day. The NGO document and Government Declaration of 2001 reflect widely applicable gains for migrants in particular, but also for refugees. The NGO document attempts to address the conference focus on racism by providing a specific acknowledgement of xenophobia as a particular form of discrimina- tion and intolerance experienced by peoplepresumed to be foreign nationals. ${ }^{49}$ Furthermore, detailed recommendations call for renewed commitment to equitable and non-discriminatory assistance for refugees in various regions of the world.

In the Final Declaration and Program of Action, ${ }^{50}$ there are many references to the protection of migrants, migrant workers, and refugees. Of particular note is paragraph 16 of the Final Declaration:

16. We recognize that xenophobia against non-nationals, particularly migrants, refugees and asylum-seekers, constitutes one of the main sources of contemporary racism and that human rights violations against members of such groups occur widely in the context of discriminatory, xenophobic and racist practices

Of note to South African NGOs participating at the NGO Forum and the WCAR was the activeinternational migrant caucus concentrating largely on the plight of migrant workers. The preparation and organization of the caucus highlighted the weaknesses of both the African region and the value of a focussed, internationally integrated caucus lobbying for refugees and asylum seekers in particular. Considering the massive refugee crisis facing the continent, the lack of participation by African NGO s in the meetings dealing with refugees and asylum seekers raised a number of questions about a lack of commitment to the issue, limited resources for organizations working in thefield, and levels of disempowerment of the refugee community themselves to actively represent their issues at a forum of this nature. Gains made at the conference were largely due to a handful of committed activists who made particularly useful contributions. ${ }^{51}$

It is of course too early to predict with any certainty whether the principles contained in the "Durban Declaration" will translate into progressive, concrete actions on the part of states to address xenophobia and racist practices towards foreigners, though it is difficult to feel positive about the future. Our fear is that, on one hand, a true commitment to these principles on the part of states will prove to be increasingly elusive, as traditionally has been the case.

The fact that powerful states withdrew or drastically reduced the strength of their delegations early on in the conference was a grim message implying a serious lack of state commi tment to these issues. On the other hand, progressive language on the rights of migrants and foreigners that was incorporated into the Declaration provides a potentially powerful tool for future advocacy. 
The challenge is now on the part of the UN, NGOs, and progressively minded governments to advocate these principles in positive, creative ways. In South Africa, there is a small but vocal group including the South African Human Rights Commission, NGOs, and CBOs advocating for the rights of refugees in South Africa. In light of the above-mentioned observation, however, there is a need to lobby at regional and continental levels to ensure that the WCAR documents assist in halting the current erosion of refugee rights in the region and the continent.

\section{Conclusions}

Apportioning blame to foreigners for the considerable socioeconomic problems of South Africa has perhaps been the most visiblefeaturein themigration debatein South Africa, with very little put forward in the way of concrete, rights-regarding solutions. Advocacy organizations on behalf of foreignershave been small in number, facing seemingly insurmountable obstaclesin their efforts to motivate for a rational policy and to change attitudes. Returning to a principled and pragmatic approach to migration policy, as advocated by the South African Draft Green Paper on International M igration and partly reflected in the Refugees Act, could be a way of reaffirming the country's commitment to social and economic development and human rights, and acknowledging the realities of why people move.

But whatever the change in policy may be, it is clear that it will have to be accompanied by a major change in attitude on the part of society and officials. Although the Roll Back Xenophobia Campaign ${ }^{52}$ has made a number of significant gains in public awareness and education targeting civil servants, the police, and the general public, it will, however, take the overt support and commitment of senior government and political leaders to make a concerted impact at changing attitudes and mindsets.

Anti-xenophobia awareness campaigns aimed at changing society's perceptions need to be adequately resourced and developed, supported as well by expanding the targeted training of police officers, immigration officers, and civil servants. Attitudes need to be changed at their core, and racism in particular needs to be addressed at a fundamental level.

The experiences of other countries might be useful in this regard. As one police officer from the N etherlands (who participated in a training program in South Africa) has noted:

police cultures have great similarities in democracies all over the world. It is culturethat often transcendsnational boundaries, and a proven way of addressing negative attitudes within the police is to improve professionalism in the force. ${ }^{53}$

In this context, promoting the exchange of officials between two countries dealing with the reception of migrants, and supporting collaborative training, might prove to be of great benefit. ${ }^{54}$ International experience should be used for examples of best practices, without ignoring the specific nature of migration in South Africa.

A new migration policy in South Africa should represent a clean break from the country's racist past, focussing more on objective realities of the country's urgent labour requirements in the context of a human-rightsregarding society (as proposed by the Green Paper), and less on issues of security. International experience has demonstrated the overwhelming failure and cost of mechanisms aimed at control, and the great value of those aimed at stimulating development.

Changing attitudes and the implementation of policy is a much greater task. In our view, there must first be an honest assessment and acknowledgement of the causes of racist, xenophobic violence perpetrated against foreigners and the implications thereof.

This year (2001), with the international community gathering in Durban, South Africa, for the United Nations-sponsored International Conference on Racism and Xenophobia, provided an ideal opportunity for reexamining these issues, although as mentioned above it is unclear to what extent the progressive principles and program of action contained in thefinal declaration will translate into concrete results.

Thesigns are that thiscould proveto bea very difficult task indeed, further worsened by the attacks of September 11, 2001, in the United States. ${ }^{55}$ Events that have followed have included numerous, shocking reports of a "backlash" against foreigners, particularly of Arabic and South Asian backgrounds, and nationals of Arabic and South Asian descent, including verbal and physical attacks and the desecration of mosques and businesses.

Finally, it has for some time been clear that governments hosting refugees and migrants are seeking to impose ever more restrictive policies regarding entry. The U nited States, which has traditionally pursued a policy of routinely detaining asylum seekers who spontaneously arrive and seek asylum, is now introducing even stronger mechanisms in regard to detention, measures to introduce tougher measures against undocumented arrivals, $^{56}$ and counter-terrorism measures that have (positively) been described as "draconian" by U.S. President Bush. While many of Australia's refugee activists werelobbying at the NGO forum, theA ustralian government was refusing Afghan asylum seekers entry to their ports. The situation for Afghan refugees has subsequently worsened with the closing of neighbouring borders in the wake of the threatened U.S. retaliation. These approaches to those seeking asylum highlight the 
need for intensified, sympathetic, and sophisticated lobbying by human rights activiststo reclaim and reaffirm theprinciples of the fledgling WCAR commitments.

Statements coming from the South African government, however, give us greater reason for hope. The government not only made considerable effort to try to convince governments not to withdraw their delegations from the WCAR, but in response to the events of September 11, the South African $M$ inistry of Foreign Affairs has issued statements calling for restraint. ${ }^{57}$ It is hoped that these same sentiments will be shared by the M inistry of Home Affairs (responsible for immigration and refugees) as well as the police and the South African public.

\section{Relevant Web Links:}

- Roll Back Xenophobia Campaign: <www.sahrc.org.za> and <www.Ihr.org.za/rollback/rollback.htm>

- Information on the National Consortium on Refugee Affairs: <www.Ihr.org.za/rollback/ncrainfo.htm>

- South African H uman RightsCommission: <www.sahrc.org.za>

- Lawyers for Human Rights Refugee Rights Project: <www.Ihr.org.za/refugee/refugeenav.htm>

- Southern African M igration Project: <www.queensu.ca/samp>

\section{Notes}

1. M ario Sevene, M ozambique M inister of Labour, reacting to the police dog "training video" portraying M ozambican nationals being set upon by dogs and police officers, PANA, Maputo, 9 N ovember 2000.

2. Part of this section is drawn from J. Handmaker and K. Singh, "Crossing Borders" [draft work-in-progress, commissioned by the Research Unit on Law and Administration, Faculty of Law, University of Witwatersrand, M ay 2001].

3. It is by now very well established that this war, described by aU.S. State department official as "one of the most brutal holocausts against ordinary human beings since W orld W ar II" (Footnote31 in Human Rights Watch infra note 21) was a conflict sponsored in part by the South African government itself.

4. Also, R. Danso and D. M cD onald, W riting Xenophobia: Immigration and the Press in Post-A partheid South Africa, ed. J Crush and D. M cD onald, SAM P M igration Policy Series, paper no. 17 (Cape Town: Southern African M igration Project, 2000).

5. J. Crush, Covert Operations: Clandestine M igration, Temporary Work and Immigration Policy in South Africa (CapeTown: Southern African Migration Project, M arch 1997).

6. J. Crush, "The Discourse and Dimensions of Irregularity in PostApartheid South Africa" (1999) 37:1 International Migration 128.

7. Ibid. at 131

8. South African Institute of Race Relations, A Survey of Race Relations in South Africa (Johannesburg: SAIRR, 1955-56, 1959-60, 1976, 1985). In 1986, influx control was abolished.

9. S. Peberdy and J. Crush, "Rooted in Racism: The O rigins of the Aliens Control Act" in J. Crush, ed., Beyond Control: I mmigration
\& Human Rightsin a Democratic South A frica (CapeTown: Southern African M igration Project, 1998) 18-36.

10. B. M asethla, "Refugee Law, Policy and Practice in South Africa" (Presentation at a workshop titled Refugee Life in South Africa: Building Partnerships for Better Solutions, organized by the NCRA, RBX, and the UNHCR, on World Refugee Day, 20 June 2001) [unpublished].

11. G. Cawthra, Policing South Africa (Cape Town: David Philip, 1993) at 1.

12. Illegal? Report on the apprehension and Detention of Suspected U ndocumented M igrants (J ohannesburg: South African H uman Rights Commission, February 1999), online $<$ www.Ihr.org.za/refugee/hrcreport.htm > See infra note 16.

13. Part of this section is drawn from both J. Handmaker and K. Singh, "Crossing Borders," supra note 2, and J. H andmaker, "N o Easy Walk" Africa Today [forthcoming].

14. Aliens Control A mendment Act N 0. 76 of 1996.

15. J. Handmaker, "Who Determines Policy? Promoting the Right of Asylum in South Africa" (1999) 11:2 International Journal of Refugee Law 294.

16. Ibid.; see also Illegal?. This was also one of the results of a wide ranging inquiry, which from M arch 1998 investigated the manner in which persons are apprehended and detained under the Aliens Control Act. Participating NGOs included W its Law Clinic, Centrefor Applied Legal Studies, and Lawyers for H uman Rights.

17. J. Klaaren, "Immigration Law and the South African Constitution" in J. Crush, ed., Beyond Control (Cape Town: Southern African M igration Project, 1998), 55-78

18. Such an approach, which identifies asylum seekers as "bogus," has been condemned by the recently appointed United Nations High Commissioner for Refugees, Ruud Lubbers, in an editorial (19 June 2001) published in The Australian; online <www.theaustralian.news.com.au/common/story_page/0,5744,214 9170\%255E7583,00.html>.

19. While most (including ourselves) would certainly support sanctions against people traffickers and unscrupulous employers, as we explain later, a policy based predominantly on punitive sanctions is unlikely to be successful. See B. Ghosh, H uddled M asses and Uncertain Shores(The H ague: Kluwer Law International, 1998).

20. B. Masethla, "Refugee Law, Policy and Practice in South Africa" (presentation at a workshop titled: Refugee Life in South Africa: Building Partnershipsfor Better Solutions, 20 June 2001).

21. Human Rights Watch, Prohibited Persons: Abuse of Undocumented M igrants, Asylum Seekers, and Refugees in South Africa (New York: H uman Rights Watch, 1998) 170; J. H andmaker, "Who Determines Policy?" supra note15 at 295.

22. J. Klaaren and C. Sprigman, "Refugee Status Determination Proceduresin South African Law" (presentation at the conference Refugees in the N ew South Africa, organized by Lawyers for H uman Rights, Pretoria, 27-29 M arch 1998) [unpublished]. 
23. In April 2000, there were around one hundred officials working within the Refugees Sub-D irectorate of the D epartment of H ome Affairs.

24. J. Klaaren and C. Sprigman, "Refugee Status D etermination Procedures in South African Law" supra note 22; W. Kerfoot, "The Lack of Due Process in Asylum Determination in South Africa" (presentation at the conferenceR efugees in theN ew South Africa, organized by Lawyers for H uman Rights, Pretoria, 27-29 M arch 1998) [unpublished]; and Z. M ajodina, Human Rights Implications of Refugee Protection (presentation at a workshop titled Refugee Life in South Africa: Building Partnerships for Better Solution, 20 June 2001) [unpublished].

25. J. H andmaker, "Who Determines Policy", ibid. at 290.

26. According to the Jesuit Refugee Services, in reality it takes between eight and ten months, as the 180 daysiscalculated from the date of the first official interview.

27. Refugee participant in Roll Back Xenophobia Campaign workshop on the rights of women refugees, N ovember 2000.

28. This situation is confirmed in a recent research report, $F$. Belvedere, P. Pigou, J. H andmaker, Realising Rights: The development of health and welfare policies for asylum seekers and refugees in South Africa (Johannesburg: Community Agency for Social Enquiry, May 2001). A similar view is held by R. Cholewinski, "Enforced D estitution of Asylum Seekersin theU nited Kingdom: The Denial of Fundamental Rights" (1998) 10:3 International Journal of Refuge Law 462.

29. A workshop was hosted by the NCRA, the Roll Back Xenophobia Campaign, and the UNHCR on World Refugee Day, 20 June 2001, to discuss issues of socio-economic rights of refugees and asylum seekers. It brought together government departments, NGOs, faith-based organizations, and others to look at a holistic and co-operative approach. A process will beinitiated for government to begin playing its rightful role in supporting refugees.

30. "Train from hell to Irene Station" Pretoria News (4 September 1998).

31. G. Okkoth-Obbo, "Does Refugee Protection in Africa N eed M e diation?' (2000) 19:3 Track Two: Refugees, Conflict and Conflict Resolution 40.

32. In B. Harris, A Foreign Space: M igration, Violence and Identity in a New Nation (2000) [unpublished; Centre for the Study of Violence and Reconciliation].

33. V. Williams, "In Need of Protection: Good Policy versus Harsh Reality for Refugees in South Africa" (2000) 9:3 Track Two: Refugees, Conflict and Conflict Resolution 9.

34. G. Reagon and J. Parsley, "Borderlines: Xenophobia... A N ew Racism? Challenges for the South Africa M edia" (2000) [unpublished, Submission to the SAHRC Hearings into Racism in the Media].

35. Ibid., cit 35.

36. G. Okkoth-Obbo, "Does Refugee Protection in Africa N eed M ediation?" (2000) 19:3 Track Two: Refugees, Conflict and Conflict Resolution

37. N. Yuval-Davis, Gender and Nation (Cape Town: Sage publications, 1997).
38. R. M attes et al., Still W aiting for theBarbarians; South Africa Attitudes to Immigrants and Immigration, SAMP Policy Series, paper no. 14 (Cape Town: Southern African M igration Project, 1999).

39. South African Human Rights Commission, Press Release in response to SAPS dog attack on non-nationals, "A 'dog eat dog' world ??" (17 November 2000).

40. Human Rights Watch, supra note 21, at 119.

41. Amnesty International, London, Press Release, "South Africa: Amnesty International wel comes Government action against racially-motivated violence by police" (8 N ovember 2000).

42. H. Radebe, "Time we becamea bit more neighbourly" The [Johannesburg] Star N ewspaper, ( $M$ arch 2000).

43. M. Monare, "Cops Assault Teacher Facing Suspension" The [Johannesburg]Star N ewspaper (13 M arch 2001).

44. The Roll Back Xenophobia Campaign, Braamfontein Statement (1998) and N ational Plan of Action; Racism and Xenophobia: A Violation of Human Rights, by the South African H uman Rights Commission, produced by the National Consortium on Refugee Affairs and the UNHCR; online: <www.sahrc.org $>$ and <www.lhr.org.za/rollback/rollback.htm>.

45. Asylum seeker speaking at a Roll Back Xenophobia Campaign media seminar titled Conflict in Africa and the Implications for Refugee M ovements, 18 June 2001.

46. The project is a partnership between the Roll Back Xenophobia Campaign, Lawyers for H uman Rights, the Centre for theStudy of Violenceand Reconciliation, and theSouth African Human Rights Commission's N ational Centre for Human Rights Training and Education.

47. Second United Nations World Conference Against Racism, Racial Discrimination, Xenophobia and Related Intolerance, held in Geneva, 1983.

48. Third United Nations W orld Conference Against Racism, Racial Discrimination, Xenophobia and Related Intolerance, held in Durban, South Africa, 31 August - 8 September 2001.

49. WCAR NGO Forum Declaration, 3 September 2001.

50. "Declaration and Programme of Action," World Conference Against Racism, Xenophobia and Related Intolerances, Durban, 24 September 2001, Agenda item 9 (to be passed as a General Assembly Resolution in the UN).

51. It is well worth noting the considerable input provided by international NGO Human Rights Watch, whose documentation was widely used by South African and other NGO s working on refugee and migrant issues as a basis for their own advocacy campaigns. For further information see online: <www.hrw.org>.

52. The Roll Back Xenophobia Campaign was launched in December 1998 in responseto therising levels of xenophobia evident in South Africa. It is a partnership project between the South African Human Rights Commission, the National Consortium on Refugee Affairs, and the UNHCR. 
53. Statement by Rob Ruts, senior partner at Ennea consultants and head of theExpert Centreon Community Policing of theN ational Police Training Institute in The N etherlands, in a discussion with J. Handmaker, 17 M ay 2001.

54. As Ruts (ibid.) has also noted, addressing attitudes amongst officials goes hand in hand with the need to address corruption, though this is nearly impossible to tackle if the police officers responsibleare barely ableto makea living on their existing salary. Strategies to improve accountability and reduce corruption, therefore, need to be tied to improvements in the working conditions of the police (including remuneration).

55. We of course refer to theterrorist attacks against theW orld Trade Center in N ew York City and the Pentagon in Washington, D.C., on 11 September 2001.

56. For a recent and useful review of U.S. policies on border control, see P. M artin, B. L. Lowell, and E. Taylor, “M igration Outcomes of Guest W orker and Free Trade Regimes: The Case of M exico US M igration" in B. Ghosh, ed., M anaging M igration (Oxford: Oxford University Press, 2000).

57. "Pahad asks US to use restraint' Pretoria News (19 September 2001).

Jeff Handmaker, LLB (N ewcastle), LLM (SOAS, London) and U.K. barrister (non-practising), is a freelance consultant, based in The $N$ etherlands and engaged in various projects concerning human rights and development co-operation.

Jennifer Parsley, BA (UCT), M A (W itwatersrand U niversity), is Coordinator of the Roll Back Xenophobia Campaign, a joint initiative of the National Consortium on Refugee Affairs (NCRA), South African Human Rights Commission (SAHRC), and UNHCR. For more information on the campaign see: www.sahrc.org <or > <www.lhr.org.za/rollback/rollback.htm>.

The views expressed in this paper are those of the authors and do not necessarily reflect the official position of the Roll Back Xenophobia Campaign partner organizations.

(C) Jeff Handmaker and Jennifer Parsley, 2001. This open-access work is licensed under a Creative Commons Attribution-NonCommercial 4.0 International License, which permits use, reproduction and distribution in any medium for non-commercial purposes, provided the original author(s) are credited and the original publication in Refuge: Canada's Journal on Refugees is cited. 